University of Nebraska - Lincoln

DigitalCommons@University of Nebraska - Lincoln

Publications, Agencies and Staff of the U.S.

Department of Commerce

U.S. Department of Commerce

1999

\title{
Hunting and social behaviour of leopard seals (Hydrurga leptonyx) at Seal Island, South Shetland Islands, Antarctica
}

\author{
Lisa M. Hiruki \\ National Marine Mammal Laboratory, Alaska Fisheries Science Center, National Marine Fisheries Service, \\ National Oceanic and Atmospheric Administration, Lisa.Hiruki@noaa.gov \\ Michael K. Schwartz \\ National Marine Mammal Laboratory, Alaska Fisheries Science Center, National Marine Fisheries Service, \\ National Oceanic and Atmospheric Administration \\ Peter L. Boveng \\ National Marine Mammal Laboratory, Alaska Fisheries Science Center, National Marine Fisheries Service, \\ National Oceanic and Atmospheric Administration
}

Follow this and additional works at: https://digitalcommons.unl.edu/usdeptcommercepub

Part of the Environmental Sciences Commons

Hiruki, Lisa M.; Schwartz, Michael K.; and Boveng, Peter L., "Hunting and social behaviour of leopard seals (Hydrurga leptonyx) at Seal Island, South Shetland Islands, Antarctica" (1999). Publications, Agencies and Staff of the U.S. Department of Commerce. 151.

https://digitalcommons.unl.edu/usdeptcommercepub/151

This Article is brought to you for free and open access by the U.S. Department of Commerce at DigitalCommons@University of Nebraska - Lincoln. It has been accepted for inclusion in Publications, Agencies and Staff of the U.S. Department of Commerce by an authorized administrator of DigitalCommons@University of Nebraska - Lincoln. 


\title{
Hunting and social behaviour of leopard seals (Hydrurga leptonyx) at Seal Island, South Shetland Islands, Antarctica
}

\author{
Lisa M. Hiruki*, Michael K. Schwartz† and Peter L. Boveng \\ National Marine Mammal Laboratory, Alaska Fisheries Science Center, National Marine Fisheries Service, National Oceanic and Atmospheric
} Administration, 7600 Sand Point Way N.E. - Bldg. \#4, Seattle, WA 98115-0070, U.S.A.

(Accepted 30 November 1998)

\begin{abstract}
The hunting behaviour of leopard seals Hydrurga leptonyx was monitored opportunistically at Seal Island, South Shetland Islands, during the austral summers from 1986/87 to 1994/95. Leopard seals used several methods to catch Antarctic fur seal pups Arctocephalus gazella and chinstrap penguins Pygoscelis antarctica, and individuals showed different hunting styles and hunting success. One to two leopard seals per year were responsible for an average of $60 \%$ of observed captures of fur seal pups. Leopard seals preyed on penguins throughout the summer, but preyed on fur seal pups only between late December and mid-February. Hunting behaviour differed significantly between different locations on the island; fur seals were hunted only at one colony, and penguins were hunted in several areas. The relative abundance of prey types, size of prey in relation to predator, and specialization of individual leopard seals to hunt fur seal prey probably influence individual prey preferences among leopard seals. On five occasions, two leopard seals were seen together on Seal Island. Possible interpretations of the relationship between the interacting leopard seals included a mother-offspring relationship, a consorting male-female pair, and an adult leopard seal followed by an unrelated juvenile. In two incidents at Seal Island, two leopard seals were observed interacting while hunting: one seal captured fur seal pups and appeared to release them to the other seal. Observations of leopard seals interacting during hunting sessions were difficult to confirm as co-operative hunting, but they strongly implied that the two seals were not agonistic toward one another. The hunting success of individual leopard seals pursuing penguins or fur seals is probably high enough for co-operative hunting not to become a common hunting strategy; however, it may occur infrequently when it increases the hunting productivity of the seals.
\end{abstract}

Key words: leopard seal, Hydrurga leptonyx, hunting behaviour, social behaviour, predation

\section{INTRODUCTION}

Leopard seals Hydrurga leptonyx are top predators in the Antarctic marine ecosystem, feeding on diverse prey including krill, fish, cephalopods, crustaceans, penguins and seals (Hamilton, 1939; Gwynn, 1953; Brown, 1957; Hofman et al., 1977; Laws, 1977; Øritsland, 1977; Bengtson, 1982; Lowry, Testa \& Calvert, 1988). The prey taken varies with the age of a seal; juvenile seals feed mainly on krill, while older seals feed on penguins, seals and other prey (Hofman et al., 1977). Krill, fish and cephalopods are eaten from September to March (Øritsland, 1977; Bengtson, 1982; Siniff \& Stone, 1985; Green \& Williams, 1986; Lowry et al., 1988). Penguins are eaten throughout the year, but form an especially

*Address correspondence to: L. M. Hiruki.

E-mail: Lisa.Hiruki@noaa.gov.

$\dagger$ Present address: Wildlife Biology Program, School of Forestry,

University of Montana, Missoula, MT 59812, U.S.A. large proportion of the leopard seal diet in January to March, when the penguins are breeding ashore and are readily available to leopard seals (Penney \& Lowry, 1967; Hunt, 1973; Müller-Schwarze \& Müller-Schwarze, 1975; Bengtson, 1982; Siniff \& Stone, 1985). Crabeater seals Lobodon carcinophagus seem to be an important part of the leopard seal diet in November to February in the pack ice near the Antarctic Peninsula, when newly weaned crabeater seal pups become available as prey (Siniff \& Bengtson, 1977; Siniff et al., 1979; Bengtson, 1982; Siniff \& Stone, 1985).

Hunting of other pinnipeds by leopard seals has rarely been observed, unlike hunting of penguins by leopard seals near penguin breeding areas, which has often been observed and described (e.g. Penney \& Lowry, 1967; Müller-Schwarze \& Müller-Schwarze, 1975; Borsa, 1990; Kooyman et al., 1990; Rogers \& Bryden, 1995; Court, 1996). Leopard seals are known to feed on other Antarctic seals (Siniff et al., 1979; Siniff \& 


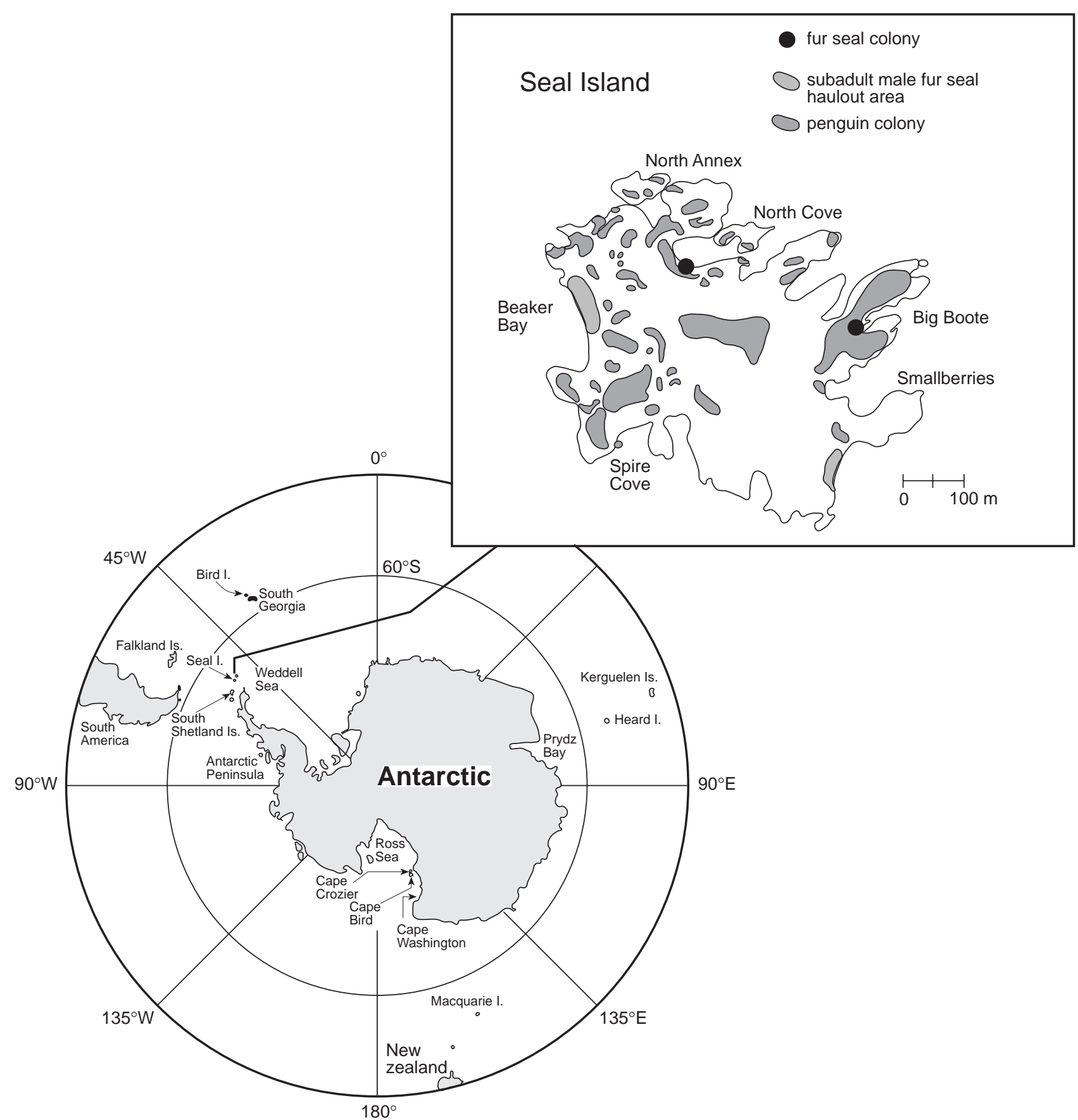

Fig. 1. Map of the Antarctic continent and surrounding subantarctic islands, with inset of Seal Island, showing Antarctic fur seal and penguin colonies.

Stone, 1985; Borsa, 1990; Erb, 1993; Shaughnessy, Erb \& Green, 1998; Walker et al., 1998), but there are few descriptions of leopard seals hunting pinniped prey due to the logistical difficulty of observing animals in the pack ice (Siniff et al., 1979) and the rareness of opportunities to observe a predation event (e.g. Gentry \& Johnson, 1981; Lopez \& Lopez, 1985). Leopard seals hunting pinnipeds have generally been seen at subantarctic islands (Borsa, 1990; Shaughnessy \& Goldsworthy, 1990; Erb, 1993; Walker et al., 1998), and not near the Antarctic continent. We describe here the hunting behaviour of leopard seals hunting Antarctic fur seals Arctocephalus gazella and penguins (primarily chinstrap penguins Pygoscelis antarctica) at Seal Island, South Shetland Islands, Antarctica. We also describe social interactions between leopard seals at Seal Island and discuss possible relationships between interacting seals.

\section{METHODS}

Seal Island $\left(60^{\circ} 59^{\prime} \mathrm{S}, 55^{\circ} 23^{\prime} \mathrm{W}\right.$; Fig. 1) lies north of Elephant Island in the South Shetland Islands, at the tip 
of the Antarctic Peninsula. Several breeding colonies of chinstrap and macaroni penguins Eudyptes chrysolophus (about 40000 and 250 breeding pairs, respectively) and 3 Antarctic fur seal colonies are located on the island (Fig. 1). The main fur seal colony, with about 200 pups born per year (Boveng et al., 1998), is located on the beach at North Cove, a cove with 2 entrances providing access from the sea to a large subtidal pool adjacent to the colony. Large pinnipeds can swim into the cove only during mid- to high tide. Sub-adult and young adult male fur seals haul out at Beaker Bay and other beaches (Fig. 1). Beaker Bay and its beach are common thoroughfares used by penguins arriving and departing from several colonies in the central area of the island. Other common corridors for penguins are Big Boote, Smallberries, Spire Cove and North Cove (informal place names used by researchers at Seal Island; Fig. 1).

Leopard seals were observed opportunistically during penguin and fur seal research, usually between 08:00 and 18:00, during the austral summers of 1987 through 1995 (years refer to the second year of the split season: e.g. 1995 refers to the 1994/95 austral summer). Leopard seals were marked (when possible) with bleach (Clairol ${ }^{1}$ Born Blonde, Clairol Inc., New York, NY, U.S.A.), Nyanzol dye (Belmar, Inc., North Andover, MA, U.S.A.) or Allflex tags (Nasco, Fort Atkinson, WI, U.S.A.), and were photographed (using a Polaroid camera with black and white film; Polaroid Corporation, Cambridge, MA, USA) or sketched (noting scars) for individual identification. Length of the seal (nose to tail, to the nearest $0.3 \mathrm{~m}$ ) was visually assessed from a distance when possible. Animals longer than $2.7 \mathrm{~m}$ were assumed to be adults, and all others assumed to be subadults (Laws, 1957). Data on sex, location, and behaviour of the seal were recorded. Sightings of the same seal were classified as separate if they were at least $3 \mathrm{~h}$ apart, or if behaviour or location had changed between sightings. One sighting per day was used in calculating frequency of sightings of individual seals. Behaviour of leopard seals was classified as either 'hunting' (pursuing, capturing, or consuming prey) or 'not hunting' (swimming, or resting with no evidence of recent hunting). If a fresh scat containing fur seal hair or penguin feathers was observed near a leopard seal hauled out on a beach, the seal was assumed to have been hunting. Hunting behaviour based on scat contents was excluded from analyses where behaviour was examined by location, as it was not known where the seal had hunted its prey. Hunting observations were further subdivided into 3 groups by the type of prey hunted (fur seals, penguins and unknown prey).

The duration of field effort differed from year to year (Fig. 2). Overall observer effort was approximately equal in 1990 through 1995, though more effort was made to identify individuals in 1990, 1993, 1994 and 1995. Observer effort during the field season was

\footnotetext{
${ }^{1}$ Reference to trade names does not imply endorsement by the National Marine Fisheries Service and National Oceanic and Atmospheric Administration.
}

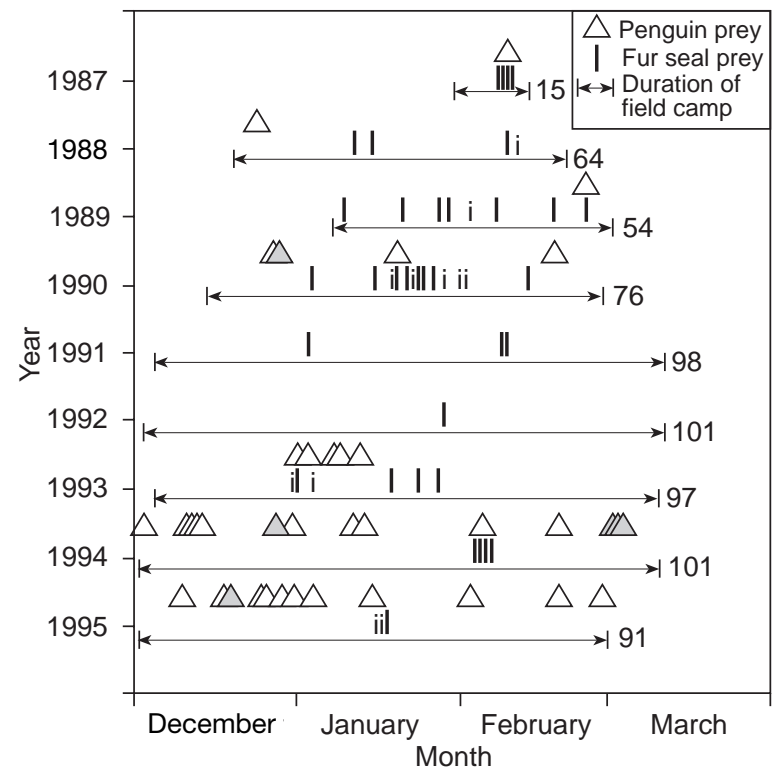

Fig. 2. Observations of leopard seals hunting Antarctic fur seal pups and penguins at Seal Island, Antarctica, showing duration of field effort, 1987-1995. Numbers indicate days of field effort. Symbols represent 1 day; shaded triangles and dotted lines represent days with two or three observations, and other symbols represent one observation per day. Observations include those in which behaviour was based on scat contents.

generally similar between years at North Cove due to daily observer presence (typically $6-10 \mathrm{~h} /$ day) for other annually recurring studies. The beach at Beaker Bay was observed during daily transits by researchers enroute to other study areas, during routine activities around camp, during weekly censuses of all pinnipeds, and during studies conducted at Beaker Bay at specific times during the season. Observations at locations other than North Cove and Beaker Bay were conducted during seasonal research activities and monthly surveys of the island; observer effort at these locations probably increased in the last 3 years of the study period.

Log-linear analyses of multi-dimensional contingency tables (Sokal \& Rohlf, 1981: 747; S-Plus loglin function) were used to test for independence between year, location and leopard seal behaviour. $G$-tests were used to test differences when data were pooled over the study period. Results were considered to be significant at the $P<0.05$ level.

\section{RESULTS}

We identified up to 12 individual leopard seals each year (Figs 3 \& 4); five seals were seen in at least two consecutive years (e.g. Fig. 4), and one was seen for four consecutive years. Identified seals were seen in $61 \%$ $(n=149)$ of 244 observations. Within each year, the number of sightings of each leopard seal varied considerably. During 1990, 1994 and 1995, when identification effort was highest (Fig. 3b), unidentified seals comprised 


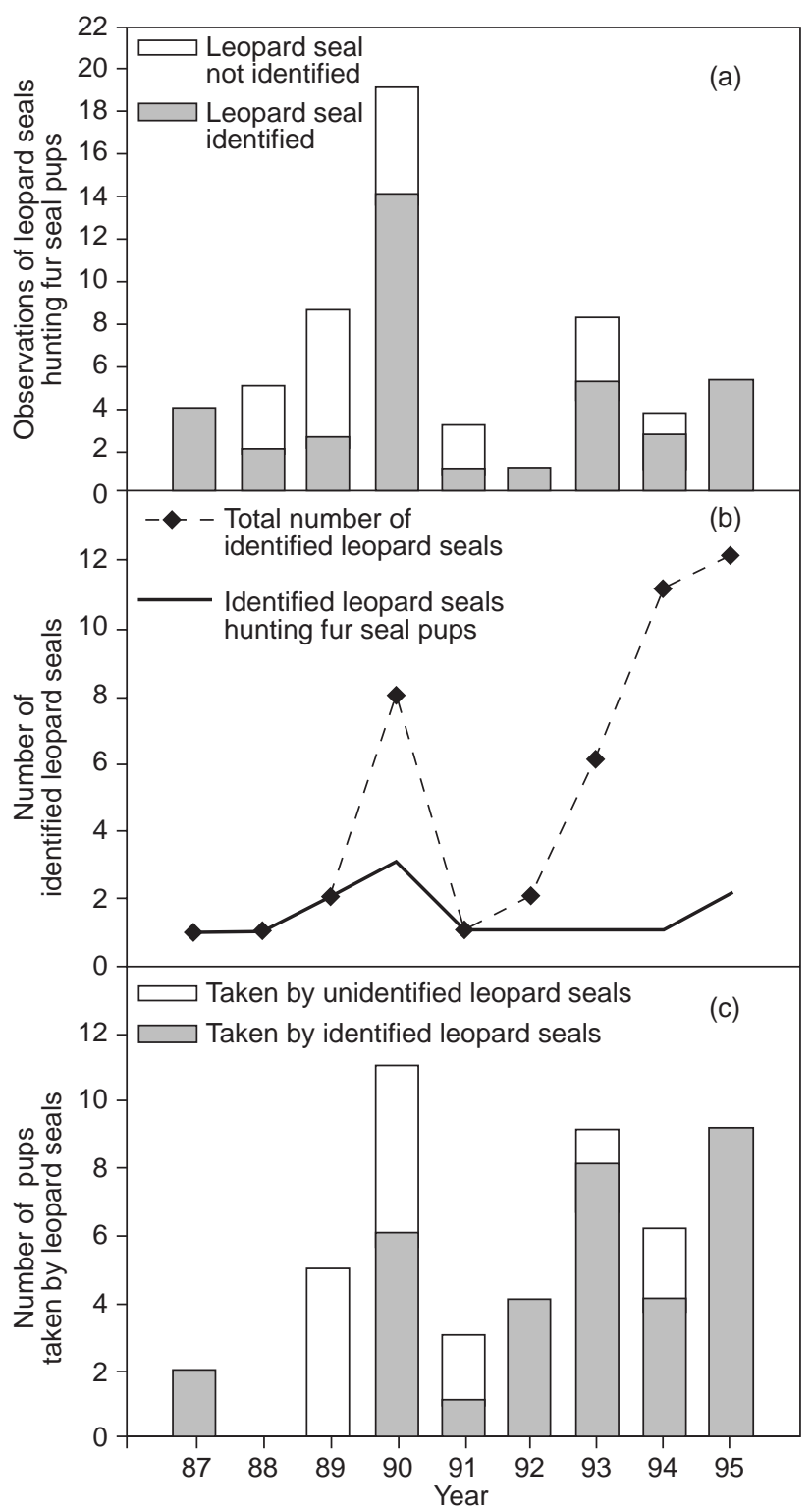

Fig. 3. Identified leopard seals hunting fur seal pups at Seal Island, Antarctica. (a) Observations of leopard seals hunting fur seal pups. (b) Number of identified leopard seals. (c) Number of pups taken by leopard seals. Observations include those in which behaviour was based on scat contents.

$25-41 \%$ of sightings (Fig. 4). The most frequently observed individual accounted for $26-33 \%$ of sightings, and the remaining $26-45 \%$ were distributed among the other identified leopard seals (Fig. 4).

One to three identified seals were associated, on average, with $70 \%$ of annual sightings of leopard seals hunting fur seal pups (Fig. 3a, b). One to two leopard seals per year were responsible for an average of $60 \%$ of observed captures of fur seal pups; in 4 years (1987, 1992, 1993 and 1995), one leopard seal was responsible for $89-100 \%$ of observed fur seal predation (Fig. 3b, c). These numbers are minimum estimates of leopard seal predation on fur seal pups, as the same leopard seals may have also been involved in fur seal hunting observations where they were not identified.
Table 1. Numbers of identified leopard seals hunting penguins, sightings of leopard seals hunting penguins, and numbers of penguins observed taken by leopard seals at Seal Island, Antarctica, 1987-1995. Numbers in parentheses indicate numbers of observations associated with identified leopard seals. Observations include data from scats

\begin{tabular}{llll}
\hline & $\begin{array}{l}\text { Number of } \\
\text { identified } \\
\text { leopard seals } \\
\text { hunting penguins }\end{array}$ & $\begin{array}{l}\text { Number of } \\
\text { sightings of } \\
\text { leopard seals } \\
\text { hunting penguins }\end{array}$ & $\begin{array}{l}\text { Number of } \\
\text { penguins } \\
\text { observed taken } \\
\text { by leopard seals }\end{array}$ \\
\hline 1987 & 0 & $1(0)$ & $1(0)$ \\
1988 & 0 & $1(0)$ & $1(0)$ \\
1989 & 1 & $0.5(0.5)^{\mathrm{a}}$ & $1(1)$ \\
1990 & 4 & $5(4)$ & $4(3)$ \\
1991 & 0 & 0 & 0 \\
1992 & 0 & 0 & 0 \\
1993 & 4 & $5(5)$ & $8(8)$ \\
1994 & 5 & $17.5(6.5)^{\mathrm{a}}$ & $15(6)$ \\
1995 & 4 & $13(5)$ & $11(5)$ \\
\hline
\end{tabular}

${ }^{\mathrm{a}} 0.5$ indicates an observation involving both fur seal and penguin prey.

One to five identified seals were associated with sightings of leopard seals hunting penguins (Table 1). The numbers of identified leopard seals observed hunting penguins were higher in the last 3 years of the study. Of 13 leopard seal scats examined, six contained fur seal hair, six contained penguin feathers, and one contained both fur seal hair and penguin feathers.

Leopard seals preyed on penguins throughout the summer (Fig. 2), but preyed on fur seal pups only between late December and mid-February, when fur seal pups were approx. 1-2 months old (Boveng et al., 1998). Examination of times of observed predation indicated a distinct peak in penguin predation from 17:00 to 18:00, whereas fur seal predation was usually seen from 15:00 to 21:00. Daily patterns of observed leopard seal predation were likely affected by observer effort (there was less effort early in the morning and late in the evening, and no effort at night).

\section{Hunting behaviour}

Leopard seals used at least three recognizable methods to catch fur seal pups:

1. Stalking - the leopard seal swam into the cove with its body submerged, exposing only its nostrils to breathe. It waited at the edge of an intertidal pool or cruised slowly along the beach and lunged suddenly at pups that approached it.

2. Rapid approach with wave - the leopard seal rode a swell toward the beach, swimming rapidly, and lunged at pups on the beach.

3. Open hunting - the leopard seal made no attempt to hide itself, entered a shallow intertidal pool at high tide, and lunged at pups.

Individual leopard seals had different hunting styles; some were stealthy, while others swam rapidly and missed frequently. After catching a pup, the leopard seal 


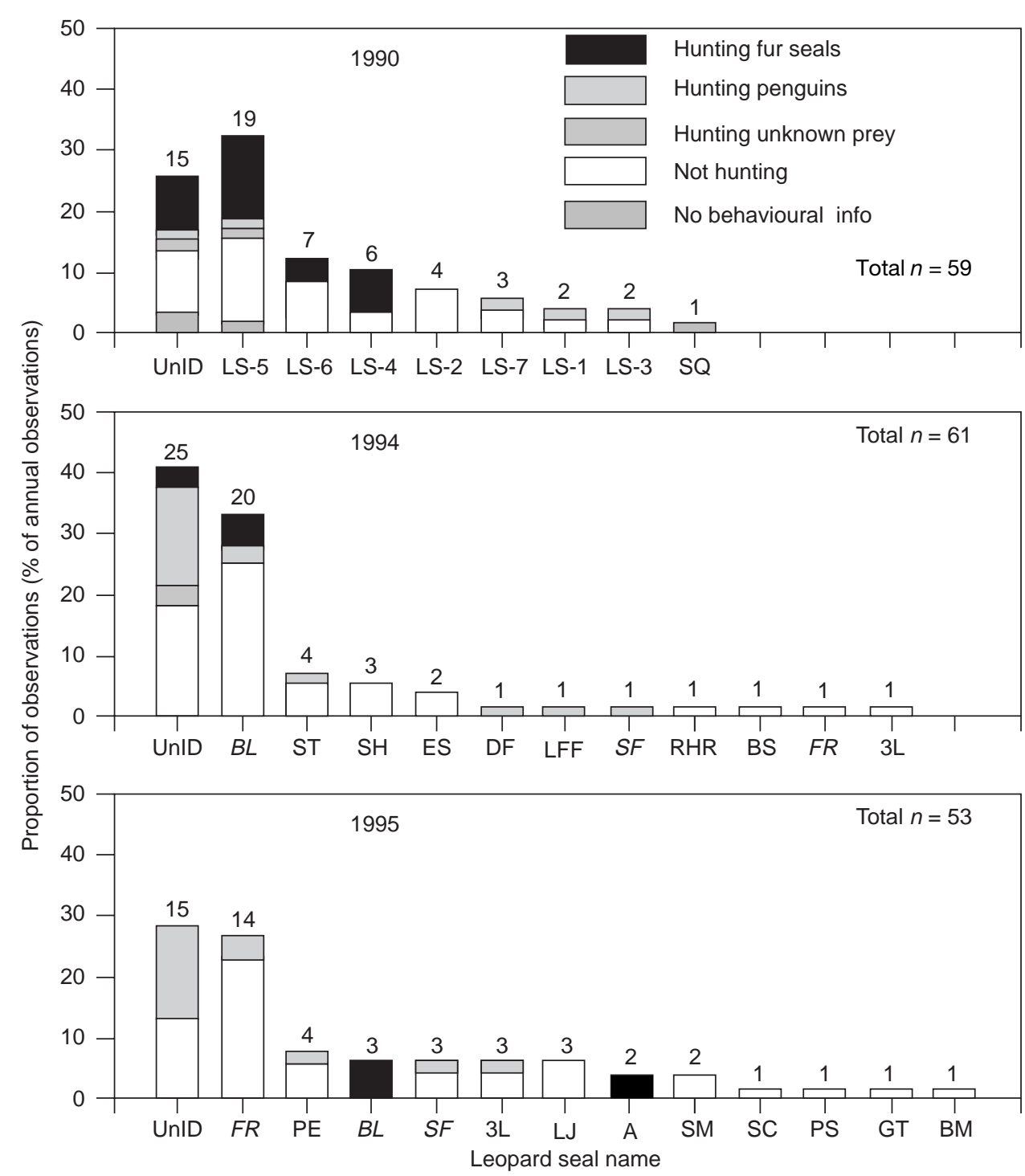

Fig. 4. Behaviour of identified leopard seals at Seal Island, Antarctica, in 1990, 1994 and 1995. Number of observations are indicated above each bar. Leopard seal names in italic indicate seals that were observed in both 1994 and 1995 . UnlD indicates that the leopard seal was not identified. Observations include those in which behaviour was based on scat contents.

swam mostly underwater, exited the cove, killed the pup outside the cove (by drowning, shaking, or thrashing it against the surface of the water), and consumed it. When leopard seals were observed outside the cove with captured pups, they released and re-captured pups (often several times) before killing and eating them. This behaviour was observed most frequently when several pups had already been consumed during the hunting session. One leopard seal played with a fur seal pup for $3 \mathrm{~min}$, and another played with two different pups for 30 and $33 \mathrm{~min}$, respectively. At least two pups escaped from a leopard seal after the initial capture, and pups were also found dead in the colony with puncture wounds on their bodies, within a day of a leopard seal sighting. The maximum rate of capture during a hunting session varied from 1.4 to $4.0 \mathrm{pups} / \mathrm{h}$ for different individuals. Leopard seals hunted only the pups of fur seals at Seal Island; sub-adult fur seals were not hunted.
From observations where both size and sex were noted, only adult female leopard seals were observed hunting fur seal pups (Table 2). Two leopard seals were observed hunting fur seal pups in consecutive years: one seal (SQ) was seen hunting fur seal pups in 1987-1989, and another (BL) was seen in 1994 and 1995.

Both adult and sub-adult leopard seals were observed hunting and eating penguins around Seal Island (Table 2). Observed methods of hunting penguins were: (1) lunge hunting - lunging through the surf at penguins in the water returning from or departing to sea, and (2) open water hunting - chasing penguins in open water. Open water hunting was also observed following an attempted ambush of swimming penguins. One adult leopard seal captured a penguin that walked nearby while the seal was hauled out on the beach. Two identified leopard seals that hunted fur seals also hunted penguins. 
Table 2. Observations of leopard seals at Seal Island, Antarctica, by size class and sex. Adults were seals with estimated length $>2.7 \mathrm{~m}$; sub-adults had estimated length $<2.7 \mathrm{~m}$. $\mathrm{M}=$ male, $\mathrm{F}=$ female, $\mathrm{U}=$ unknown sex

\begin{tabular}{|c|c|c|c|c|c|}
\hline \multirow[b]{2}{*}{ Size class } & \multirow[b]{2}{*}{ Sex } & \multicolumn{3}{|c|}{ Observations of hunting behaviour } & \multirow{2}{*}{$\begin{array}{l}\text { Not hunting or no } \\
\text { behavioural data }\end{array}$} \\
\hline & & Fur seal prey & Penguin prey & Unknown prey & \\
\hline \multirow[t]{3}{*}{ Adult } & M & 0 & 0 & 0 & 5 \\
\hline & $\mathrm{F}$ & 20 & 8 & 1 & 53 \\
\hline & $\mathrm{U}$ & 15 & 9 & 0 & 13 \\
\hline \multirow[t]{3}{*}{ Sub-adult } & $\mathrm{M}$ & 0 & 5 & 0 & 21 \\
\hline & $\mathrm{F}$ & 0 & 0 & 0 & 4 \\
\hline & $\mathrm{U}$ & 0 & 3 & 0 & 4 \\
\hline \multirow[t]{3}{*}{ Size not recorded } & M & 1 & 3 & 0 & 1 \\
\hline & $\mathrm{F}$ & 0 & 1 & 0 & 3 \\
\hline & $\mathrm{U}$ & 21 & 14 & 5 & 34 \\
\hline
\end{tabular}

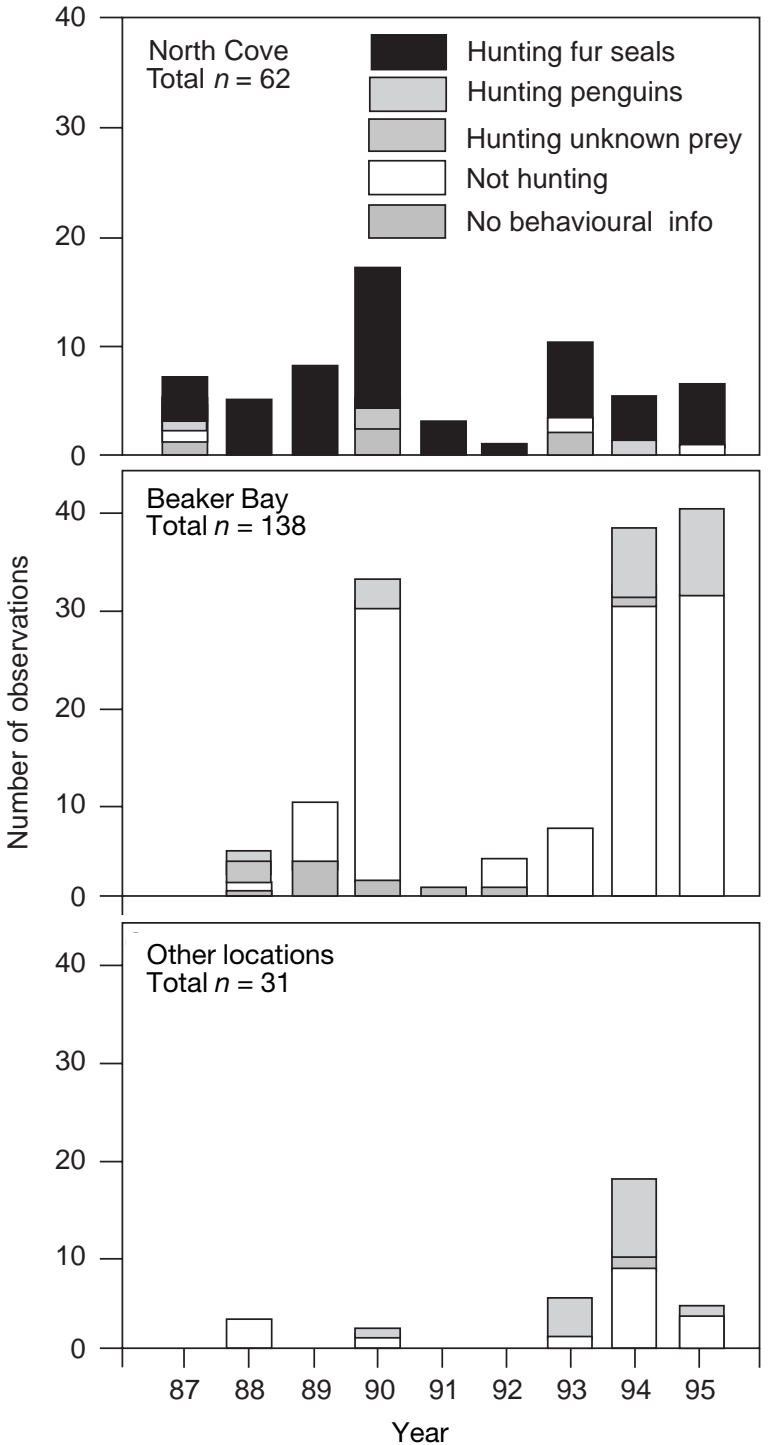

Fig. 5. Leopard seal behaviour at different locations on Seal Island, Antarctica, 1987-1995. Observations where behaviour was based on scat sightings were excluded.
The behaviour of leopard seals (hunting or not hunting) was independent of year $(G=17.46$, d.f. $=16$, $P=0.36$ ) but was not independent of location (North Cove $v s$ all other locations combined; $G=95.90$, d.f. $=9$, $P<0.001$; Fig. 5). When data from all years were combined, a significantly higher proportion of hunting behaviour was seen at North Cove, compared to other locations $(G=98.47$, d.f. $=1, P<0.001)$. The type of prey hunted (fur seals vs penguins, excluding unknown prey) was independent of year $(G=6.95$, d.f. $=16$, $P=0.97$ ), but not independent of location (North Cove $v s$ all other locations combined; $G=72.49$, d.f. $=9$, $P<0.001)$. When all years were combined, significantly different proportions of the two types of prey were hunted at different locations $(G=99.98$, d.f. $=1$, $P<0.001)$ : fur seals were hunted only at North Cove, whereas penguins were hunted primarily at other locations (Fig. 5).

\section{Social behaviour and interaction between seals while hunting}

Two leopard seals were observed together on five occasions at Seal Island. In two of these observations, one leopard seal was larger than the other (obs. 3.12 and 3.17, Table 3). In obs. 3.17, the larger seal hunted while the other seal waited nearby. In 1988, two leopard seals were seen hunting at the same time, apparently independently, in North Cove (obs. 3.18, Table 3).

In 1995, an adult female leopard seal (BL) hunted fur seal pups on two consecutive days in North Cove, accompanied by a second seal (obs. 4.3 and 4.4, Table 4). The second seal was adult size (approx. $3 \mathrm{~m}$ long), but of unknown sex. On 15 January 1995, while BL hunted in North Cove, the second leopard seal waited at the entrance to North Cove. BL captured one fur seal pup; subsequently, an unidentified leopard seal was seen outside the cove consuming the pup. BL captured three more fur seal pups. After one of these captures, she and the other seal were seen outside the cove with the pup. It was not clear whether BL was releasing the captured pup to the other leopard seal, whether both seals were consuming the pup during the time that they were 
Table 3. Observations of two or more leopard seals interacting or seen in close proximity at subantarctic islands and near the Antarctic continent

\begin{tabular}{|c|c|c|c|c|c|}
\hline Obs. no. & Month & Description of sighting & Context & Location & Source \\
\hline \multicolumn{6}{|c|}{ Observations on subantarctic islands } \\
\hline 3.1 & Early September & $\begin{array}{l}\text { Large leopard seal accompanied by a much smaller one, swimming along the coast. } \\
\text { On one pass, the } 2 \text { leopard seals were followed by an even smaller leopard seal }\end{array}$ & Unknown & Heard Island & Erb (1993) \\
\hline 3.2 & $\begin{array}{l}\text { Late September } \\
\quad \text {-early October }\end{array}$ & $\begin{array}{l}\text { Two sightings of } 2 \text { leopard seals, one larger than the other, 'playing'. On } 29 \text { Sept., } \\
\text { the larger seal was trying to rest its head on the smaller seal's hindquarters, while } \\
\text { the smaller seal attempted to avoid the larger. On } 8 \text { Oct., a leopard seal was seen } \\
\text { sniffing at the penile orifice of a second seal; the } 2 \text { appeared to be immature seals } \\
\text { and were thought to have been lying close together the previous evening }\end{array}$ & Playing/ mating & Heard Island & Gwynn (1953) \\
\hline 3.3 & Early October & $\begin{array}{l}6 \text { Oct. } 1957 \text {, a female leopard seal and juvenile seal }(1.5 \mathrm{~m} \text { long) seen in close } \\
\text { proximity on rocks; they entered the water together }\end{array}$ & Mother and pup? & Iles Kerguelen & Estève (1959) \\
\hline 3.4 & Early January & $\begin{array}{l}9 \text { Jan. 1980, spaced group of } 4 \text { adult seals (unknown sex) hauled out on a small } \\
\left(72 \mathrm{~m}^{2}\right) \text { sandy beach, near large colonies of macaroni penguins }\end{array}$ & Unknown & Iles Kerguelen & Bester \& Roux (1986) \\
\hline 3.5 & Late January & $\begin{array}{l}29 \text { Jan. 1984, spaced group of } 5 \text { adult seals ( } 2 \text { female, } 3 \text { unknown sex) hauled out } \\
\text { on a small }\left(72 \mathrm{~m}^{2}\right) \text { sandy beach, near large colonies of macaroni penguins }\end{array}$ & Unknown & Iles Kerguelen & $\begin{array}{l}\text { Bester \& Roux } \\
\quad(1986)\end{array}$ \\
\hline 3.6 & Late January & $\begin{array}{l}\text { On } 31 \text { Jan., } 2 \text { adult leopard seals, after having caught and eaten several penguins, } \\
\text { proceeded to swim and display in tandem. The smaller animal followed the other in } \\
\text { quite processional swimming, nuzzling its hind flippers and then repeatedly rolling } \\
\text { over it from behind, as if attempting some sort of mating position. On about } 10 \text { or } \\
\text { more occasions, the smaller animal grasped the larger half way along its body }\end{array}$ & Playing/mating & Heard Island & Erb (1993) \\
\hline 3.7 & Austral winter & $\begin{array}{l}\text { Groups of } 2-3 \text {, and occasionally up to } 7 \text {, leopard seals involved in apparent } \\
\text { copulatory behaviour }\end{array}$ & Playing/mating & $\begin{array}{l}\text { Bird Island, South } \\
\text { Georgia }\end{array}$ & Walker et al. (1998) \\
\hline \multicolumn{6}{|c|}{ Observations on Antarctic islands and continent } \\
\hline 3.8 & Early August & $\begin{array}{l}\text { A large }(3.6 \mathrm{~m}) \text { female and small }(2 \mathrm{~m}) \text { male were seen lying on the ice in close } \\
\text { proximity; the male approached the observer several times, and appeared to be } \\
\text { defending the female }\end{array}$ & Mating & $\begin{array}{l}\text { Davis Station, } \\
\text { Prydz Bay }\end{array}$ & Erb (1993) \\
\hline 3.9 & October & $\begin{array}{l}11 \text { Oct. 1995, } 2 \text { leopard seals were seen swimming within } 5 \mathrm{~m} \text { of each other, } \\
\text { heading south, and a third seal about } 10 \mathrm{~m} \text { away was killing an Adélie penguin }\end{array}$ & Unknown & $\begin{array}{l}\text { King George Island, } \\
\text { South Shetland } \\
\text { Islands }\end{array}$ & $\begin{array}{l}\text { T. Mader, pers. } \\
\text { comm. }\end{array}$ \\
\hline 3.10 & November & $\begin{array}{l}\text { A small leopard seal (larger than a pup) following and copying hunting behaviour } \\
\text { of } 2 \text { larger seals; method used was unusual (coming up onto the ice to capture } \\
\text { emperor penguins) }\end{array}$ & Learning to hunt? & Cape Washington & $\begin{array}{l}\text { G. Kooyman, pers. } \\
\text { comm. }\end{array}$ \\
\hline 3.11 & Mid-November & $\begin{array}{l}\text { Two male leopard seals fighting; } 1 \text { male had been paired with a female leopard } \\
\text { seal when the second male approached }\end{array}$ & Mating & Ross Sea (on ice) & Shaughnessy (1990) \\
\hline 3.12 & December & $\begin{array}{l}11 \text { Dec. 1993, } 2 \text { seals swimming together, the larger seal (tentatively identified as } \\
\text { female) had hunted and caught a penguin before the } 2 \text { seals were seen together }\end{array}$ & Unknown & Seal Island & Present study \\
\hline 3.13 & December? & $\begin{array}{l}\text { Large adult female hunting penguins, followed by a small (yearling?) seal, scavenging } \\
\text { carcasses of penguins caught and discarded by the female. These } 2 \text { seals seen close } \\
\text { together }(<5 \mathrm{~m} \text {, compared to }>20 \mathrm{~m} \text { distance maintained by other leopard seals } \\
\text { hunting in the area) but were not seen interacting together. No aggression was seen }\end{array}$ & Unknown & $\begin{array}{l}\text { Cape Bird, Ross } \\
\text { Island }\end{array}$ & $\begin{array}{l}\text { G. Court, pers. } \\
\text { comm. }\end{array}$ \\
\hline 3.14 & January & $\begin{array}{l}\text { Three leopard seals seen 'playing': vocalizing and making mock passes with open } \\
\text { mouths while swimming }\end{array}$ & Playing & $\begin{array}{l}\text { Cape Crozier, Ross } \\
\text { Island }\end{array}$ & Kooyman (1965) \\
\hline 3.15 & February & Two leopard seals 'fighting'; speculated to be mating behaviour & Mating? & Weddell Sea & Wild (1923) \\
\hline 3.16 & February & Up to 3 leopard seals swimming together & Unknown & not given & Hamilton (1939) \\
\hline
\end{tabular}


Table 3 (continued)

\begin{tabular}{|c|c|c|c|c|c|}
\hline Obs. no. & Month & Description of sighting & Context & Location & Source \\
\hline 3.17 & February & $\begin{array}{l}9 \text { Feb. } 1987,2 \text { leopard seals seen, } 1 \text { larger than the other. The larger one was } \\
\text { repeatedly releasing and recapturing a penguin while the smaller one waited nearby }\end{array}$ & Unknown & Seal Island & Present study \\
\hline 3.18 & February & $\begin{array}{l}11 \text { Feb. 1988, } 2 \text { leopard seals seen hunting in North Cove fur seal colony at the same } \\
\text { time. The } 2 \text { seals were assumed to be hunting separately }\end{array}$ & Unknown & Seal Island & Present study \\
\hline \multicolumn{6}{|c|}{ Observations of leopard seals in captivity } \\
\hline 3.19 & $\begin{array}{l}30 \text { Nov., January- } \\
\text { February }\end{array}$ & $\begin{array}{l}\text { Mounting, copulation and attempted copulation were observed between a male and } \\
\text { female in captivity }\end{array}$ & Mating & $\begin{array}{l}\text { Taronga Zoo, } \\
\text { Sydney }\end{array}$ & Marlow (1967) \\
\hline 3.20 & December-January & $\begin{array}{l}\text { Mounting and attempted mounting were observed frequently between a male and } \\
\text { female leopard seal in captivity }\end{array}$ & Mating & $\begin{array}{l}\text { Taronga Zoo, } \\
\text { Sydney }\end{array}$ & Rogers et al. (1996) \\
\hline
\end{tabular}

Table 4. Observations of leopard seals interacting while hunting

\begin{tabular}{|c|c|c|c|c|}
\hline Obs. No. & Month & Description of sighting & Location & Source \\
\hline 4.1 & October & $\begin{array}{l}\text { Two leopard seals hunting emperor penguins; } 1 \text { seal waited in a tide crack in the ice, facing out into open } \\
\text { water, while the other shepherded } 10 \text { penguins in the water, along the fast ice edge, towards the tide } \\
\text { crack. The penguins left the water before reaching the tide crack; no kill was observed. The seal that } \\
\text { shepherded the penguins joined the other in the tide crack, then left the area after } 5 \text { min }\end{array}$ & Prydz Bay & J. Grey, pers. comm. \\
\hline 4.2 & December & $\begin{array}{l}\text { Two leopard seals co-operatively hunting Adélie penguins, approx. } 40 \mathrm{~m} \text { offshore from a major penguin } \\
\text { colony (Magnetic Island); at this time, there was no fast ice cover near shore. One seal chased } 4-5 \\
\text { Adélie penguins, driving them towards shore, and another ambushed the group of penguins as they } \\
\text { passed a group of ice floes. The ambush seal killed and ate a penguin, and the driver seal killed a penguin } \\
\text { and left it floating near the ambush seal, who then ate it. The ambush seal then returned to the ice floes, } \\
\text { while the driver seal swam away from shore on a circular route. The seals then repeated the sequence of } \\
\text { events, killing } 3 \text { more penguins ( } 1 \text { by each seal, followed by the driver seal catching a penguin that came } \\
\text { around the ice floe while the seal was eating), and both swam away. The ambush seal was larger than the } \\
\text { driver seal. The location of this sighting was about } 5 \mathrm{~km} \text { from observation } 4.1\end{array}$ & Prydz Bay & J. Grey, pers. comm. \\
\hline 4.3 & January & $\begin{array}{l}15 \text { Jan. 1995, } 2 \text { leopard seals, both adult size, } 1 \text { female, seen hunting in North Cove fur seal colony. Female } \\
\text { hunted and caught pups. Both seals were observed outside the cove with the prey, but it was not clear } \\
\text { whether one or both seals were consuming the prey. See text for details }\end{array}$ & Seal Island & Present study \\
\hline
\end{tabular}

4.4 January 16 Jan. 1995, 2 leopard seals, both adult size, 1 female, seen hunting in North Cove fur seal colony. Female Seal Island hunted and caught pups, and released them to the other seal, which ate them. See text for details

Present study 
outside the cove, or whether BL was keeping the pup away from the other seal. On 16 January 1995, BL was observed hunting in North Cove, with a leopard seal present at the entrance of North Cove. BL caught a fur seal pup and released it to the other leopard seal before immediately returning to the cove to hunt again while the other seal consumed the fur seal pup. This sequence of events was repeated twice more (a total of three pups was caught and released to the other seal). BL caught two more pups: one pup escaped, possibly as she was releasing it to the other seal, and she appeared to keep possession of the last pup. BL left the cove following several unsuccessful attempts to catch pups. The second leopard seal remained at the entrance of North Cove for at least 30 min after BL left. BL was seen the following day (17 January 1995) hunting alone in North Cove.

\section{DISCUSSION}

\section{Hunting behaviour}

The behaviour of leopard seals hunting penguins and fur seal pups at Seal Island was similar to descriptions of leopard seals hunting Adélie penguins Pygoscelis adeliae (Conroy et al., 1975; Müller-Schwarze \& MüllerSchwarze, 1975; Rogers \& Bryden, 1995; Court, 1996) and hunting behaviour observed in other pinniped species hunting pinniped prey (Gentry \& Johnson, 1981; Pitcher \& Fay, 1982; Harcourt, 1993). Both male and female leopard seals were seen at North Cove hunting fur seals (Table 2), similar to observations of male and female leopard seals hunting penguins at Prydz Bay (Rogers \& Bryden, 1995), but in contrast to some pinniped species where only males have been observed hunting seals (Gentry \& Johnson, 1981; Pitcher \& Fay, 1982; Harcourt, 1993; Byrnes \& Hood, 1994). Size of predator in relation to prey may influence prey choice here: both male and female adult leopard seals are large enough to take large prey such as fur seal pups, while smaller prey such as penguins are available to both adult and sub-adult leopard seals (Rogers \& Bryden, 1995); however, only male otariid seals (larger than the females) are large enough to take large prey such as other seals (Gentry \& Johnson, 1981; Harcourt, 1993) or, in a unique situation, adult king penguins (Hofmeyr \& Bester, 1993).

Competition for access to areas around fur seal colonies (Borsa, 1990; Walker et al., 1998) may be another factor limiting the number of leopard seals hunting fur seal pups at Seal Island. Only a few leopard seals were seen to do most of the fur seal predation (Fig. 3), and the same adult leopard seals were seen hunting fur seal pups in several consecutive years (Fig. 4). Sub-adult leopard seals, presumably subordinate to adults, were never seen hunting fur seal pups at Seal Island (Table 2). Up to five identified leopard seals per year (Table 1), both adult and sub-adult (Table 2), hunted penguins at Seal Island (similar to observations at Prydz Bay; Rogers \& Bryden, 1995); perhaps penguins were abundant enough that competition did not limit the number of hunting leopard seals.
The diet of individual leopard seals probably varies with the relative abundance of available prey. The number and frequency of individuals hunting fur seals at Seal Island could depend on the relative abundance of fur seals, and the locations where fur seals were available, compared to penguins. Fur seals at Seal Island were a more limited resource than penguins, as there were only a few areas where seals could be captured (Fig. 1), and fur seal colonies were small (Boveng et al., 1998). In addition, fur seal colonies were located in areas with protected inshore waters, which may have limited access for large pinnipeds such as leopard seals (Boveng et al., 1998), especially at low tide. Penguin colonies on Seal Island were more plentiful, with about 40000 breeding chinstrap penguins, each departing from or returning to the island approx. twice per day (Jansen, Boveng \& Bengtson, 1998) at locations that were easily accessible to leopard seals (Fig. 1). It would be expected, therefore, that relatively few leopard seals would prey on fur seal pups compared to the number preying on penguins.

At Bird Island, where fur seals are a major winter prey item of leopard seals (58\% of observed kills and $53 \%$ of scats involved fur seals; Walker et al., 1998), a substantial population of fur seals is available (an estimated number of 64545 adult females, producing an approximate total of 45827 pups in 1990/91; Boyd, 1993). Furthermore, the most abundant penguin species (macaroni penguin) at Bird Island departs for the winter (Williams \& Croxall, 1991) a few weeks before leopard seals arrive in late April (Walker et al., 1998). The overwintering colonies of gentoo penguins Pygoscelis papua are greatly outnumbered by the overwintering fur seals (Croxall \& Prince, 1979). Thus, it is not surprising that leopard seals prey on fur seals more than penguins at Bird Island during the winter. Similarly, the greatest number of leopard seals at Heard Island are seen when the most abundant penguin species have departed for the winter, and the remaining gentoo penguins are not numerous enough to support the overwintering leopard seal population (Gwynn, 1953). Leopard seal predation on fur seal and elephant seal juveniles was observed mostly during winter, with many fewer pinniped captures seen once penguins returned in late spring (Shaughnessy \& Goldsworthy, 1990; Erb, 1993; Shaughnessy et al., 1998).

Although leopard seals fed on chinstrap penguins around Seal Island throughout the austral summer, the availability of fur seal pups as prey for leopard seals appeared to be restricted to a 2-month window (Fig. 2) when pups were old enough to enter the water, but were still naive enough to allow a leopard seal to approach closely. Leopard seals at Seal Island were never seen to hunt sub-adult or adult fur seals, in contrast to observations at Bird and Heard Islands, where leopard seals often prey on juvenile fur and elephant seals (Erb, 1993; Shaughnessy et al., 1998; Walker et al., 1998). It appears that, during the austral summer at Seal Island, leopard seals hunt the age group of fur seals that is the easiest prey (pups of the year). Fur seal pups born on 
subantarctic islands are probably not subject to significant leopard seal predation during the same period as pups at Seal Island because leopard seals generally do not move north to these islands until April or May (Rounsevell \& Eberhard, 1980; Walker et al., 1998). When leopard seals arrive at subantarctic islands, they may also take advantage of the easiest prey (i.e. pups of the year) and feed heavily on them if the seal population persists there through the winter. Leopard seals are present all year at some islands (Heard Island: Csordas, 1963; Kerguelen Islands: Bester, 1981; Bester \& Roux, 1986), and cause some Antarctic fur seal pup deaths during the austral summer (Borsa, 1990; Shaughnessy \& Goldsworthy, 1990).

In many years when fewer than 10 pup captures were observed at Seal Island, the number of pups at North Cove dropped by about 90 individuals (Boveng et al., 1998). The timing of decreases in daily pup counts corresponded with observations of leopard seals hunting in North Cove, suggesting that most of the leopard seal predation on fur seal pups was not observed directly. Boveng et al. (1998) estimated the number of North Cove fur seal pups taken by leopard seals to be 165 in 1990, approx. double the annual numbers estimated taken in 1991 through 1995. Estimates of the numbers of fur seal pups taken in 1991 (81, 34\% of pups born) and 1992 (76, 33\% of pups born) were comparable to numbers estimated for 1993, 1994 and 1995 (32-38\% of pups born for those years; Boveng et al., 1998), indicating that the number of observed predations (Fig. 3a), rather than the number of actual predation events, was low in 1991 and 1992. The contrast between the number of observations of leopard seal predation on fur seal pups (Fig. 3a, c) and the estimated numbers of pups taken by leopard seals (Boveng et al., 1998) indicates that very few (3.7-14.3\%) actual predation events were observed.

Fur seal pup predation was observed primarily in the afternoon (15:00-21:00). Leopard seals have been observed to be most active between 17:00 and 03:00 (Müller-Schwarze, 1971), however, and given that few of the actual fur seal predation events at Seal Island were observed, leopard seals probably also hunted fur seal pups in the late evening, night, or early morning when observer effort was minimal. The diurnal timing of penguin predation by leopard seals may relate to the timing of penguin movements; during the period of greatest penguin predation (17:00-18:00), there is a peak in the number of chinstrap penguins departing from and returning to Seal Island (Jansen et al., 1998).

\section{Social interactions between leopard seals}

Leopard seals are generally solitary: most observations have been of single animals (Gilbert \& Erickson, 1977), and when hunting in the same area, seals are usually widely spaced (Penney \& Lowry, 1967; Rogers \& Bryden, 1995). Interactions between leopard seals, though not common, have been observed (Tables $3 \&$
4), mostly in situations assumed to be mating or playing contexts (Table 3). When leopard seals are abundant in one location (e.g. a wintering area), they may practise social behaviour, as juveniles of more gregarious species do (Rasa, 1971; Gentry, 1974; Harcourt, 1991; see Bekoff \& Byers, 1985 for a review of juvenile mammals). Social play in normally solitary animals may also be used to assess opponents in a non-competitive environment (Latour, 1981).

Some leopard seal interactions observed at Seal Island and other locations could not easily be categorized as mating or playing behaviour (Table 3). In several of these observations, two seals were swimming together or were in close proximity but not actively associating. One animal was often larger than the other, with the smaller seal following or waiting near the larger one. The close proximity of the seals in the observations in Table 3 raises questions about the potential benefits of sociality in such situations. Sociality outside the context of copulation may enhance the fitness of individual participants in several ways: (1) an experienced animal may associate with less experienced but related individuals, such as siblings or offspring; (2) reproductively mature animals may benefit from establishing a bond outside the breeding season, possibly to practice the skills leading to copulation; (3) unrelated young animals may benefit through group foraging, or by following a tolerant, experienced individual.

In the first case, a mother-offspring relationship may be the most likely pairing to consider. Leopard seals have their pups on the pack ice from late October to December (DeMaster et al., 1980; Laws, 1984; Siniff \& Stone, 1985), and females are thought to nurse their pups for about 1 month (Laws, 1984). Of one October observation (obs. 3.3) and two December observations (obs. 3.12 and 3.13, Table 3) of a large and a small seal in close proximity, the larger of the pair was a female (tentatively identified in obs. 3.12), and the smaller one could have been its pup. It is possible that the smaller seal in obs. 3.3 was the pup of the female, as pregnant females have been observed in September at Iles Kerguelen (Paulian, 1953; Estève, 1959). It is unlikely, however, that the two seals in obs. 3.12 and 3.13 were lactating mothers and their pups because Antarctic pack ice-breeding seals are not known to nurse their pups away from the ice. In phocid seals where weaning has been observed, the pup is weaned by the departure of the mother (Riedman, 1990), and further contact between mother and offspring has not been documented. Usually, a prolonged bond between mother and weaned offspring is found in highly social animals (e.g. killer whales Orcinus orca: Heimlich-Boran, 1986; bottlenose dolphins Tursiops truncatus: Tavolga \& Essapian, 1957), although in some solitary felids the mother-offspring bond can persist after the offspring is independent (Schaller \& Cranshaw, 1980; Le Roux \& Skinner, 1989). Pinniped species in which there is thought to be some degree of post-weaning motheroffspring contact are social otariid species (e.g. California sea lions Zalophus californianus: Hanggi \& 
Schusterman, 1990) rather than solitary species. What is known about sociality in leopard seals, therefore, does not suggest that females and their weaned pups interact.

Though breeding leopard seal pairs consorting outside the breeding season have not been documented, it is possible that the leopard seals observed socializing may be breeding pairs. Mature male leopard seals are slightly smaller than adult female leopard seals (Laws, 1957), which could account for the size difference seen in observations of two interacting seals. Leopard seal breeding is thought to occur in December to January (Siniff \& Stone, 1985; Rogers, Cato \& Bryden, 1996), a month after the pupping season. Some of the assumed mating observations in Table 3 were observed outside the breeding season, and may have involved sub-adult male leopard seals guarding or consorting with anoestrous females or other immature males. More information is necessary to investigate this interpretation.

The size discrepancy in observations of leopard seal pairs could also be attributed to young animals following unrelated older animals with more hunting experience. In three observations of leopard seal pairs (obs. 3.10, 3.13, 3.17; Table 3), the smaller seal followed or waited nearby as the larger seal hunted. In obs. 3.10, the smaller seal appeared to be imitating the larger seals in their hunting technique, similar to killer whales learning stranding behaviour to hunt seals (Lopez \& Lopez, 1985; Guinet, 1991; Guinet \& Bouvier, 1995). In obs. 3.13, the smaller seal scavenged from carcasses left by the adult. Sub-adult leopards Panthera pardus (Bailey, 1993) occasionally stay close to unrelated tolerant adults, to scavenge from prey carcasses that the adults leave behind. Given the solitary nature of leopard seals, it is possible that juvenile leopard seals follow unrelated adults to learn hunting techniques or to obtain access to discarded carcasses.

Social interactions between normally solitary conspecifics during hunting are rare, and often difficult to interpret (Table 4). Strategies used by individuals during interactions influence the outcome (co-operative, commensal, parasitic or competitive) of the association. Packer \& Ruttan (1988) analysed group hunting behaviour in a model where individuals use one of four strategies: (1) co-operator (hunt actively when with a companion); (2) scavenger (never hunt, but exploit any hunting behaviour of a companion); (3) cheater (hunt only if the individual sees prey first, otherwise scavenge); (4) solitary (avoid conspecifics and always hunt alone). The number and size of prey relative to the size of the predator can also affect the interactions between hunters. Packer \& Ruttan (1988) predict that for situations where animals are hunting single or multiple prey small enough to be monopolized by the captor (as in the case of leopard seals hunting penguins or fur seals), the solitary strategy tends to be an evolutionarily stable strategy (Maynard Smith, 1974) unless co-operation between individuals increases net hunting productivity (increases the number of prey caught or decreases the amount of energy required to catch prey) of the animals.
It is difficult to confirm co-operative behaviour from the observed incidents in Table 4. Obs. 4.1 from Prydz Bay (Table 4) does not necessarily indicate co-operative hunting, but there is some indication of affiliative behaviour, since the two seals remained together for 5 min before leaving the area. The driving (or chasing) and ambush behaviours exhibited by each leopard seal in obs. 4.2 (Table 4) have been observed in solitary hunters (Müller-Schwarze, 1984; Rogers \& Bryden, 1995); the seals may have interacted as a result of their individual hunting strategies and not as a co-operative effort. The two seals repeated the sequence of events and killed three more penguins, however, suggesting that their behaviour was not incidental and probably not agonistic towards one another. In observations of two leopard seals interacting at Seal Island (obs. 4.3 and 4.4, Table 4), the hunting leopard seal may have released her prey after being threatened by the second leopard seal, as occurs in inter- and intraspecific kleptoparasitism in birds (Brockmann \& Barnard, 1979); however, no above-water threats were observed during the interactions. As in obs. 4.2 (Table 4), the behaviour of the two seals at Seal Island was not incidental: the seals repeated the sequence of events (the female releasing captured pups to the other seal) several times in the hunting session, suggesting that the seals were not agonistic toward one another and that the female may have voluntarily released the pup to the second seal. Because leopard seals display underwater agonistic behaviour (Rogers et al., 1996; G. Kooyman, pers. comm.), both underwater and above-water observations would be necessary to confirm that there were no agonistic interactions between the two seals.

The hunting success of individual leopard seals pursuing penguins or fur seal pups is probably high enough for there to be little incentive for seals to co-operate frequently while hunting. A single leopard seal may catch as many as 4.9-6.0 penguins/h (Kooyman, 1965; Rogers \& Bryden, 1995). With a more common hunting rate of about 1.4-2.2 penguins/h (Hunt, 1973; Rogers \& Bryden, 1995; Court, 1996), if a leopard seal takes an average of 8 penguins/day (Müller-Schwarze, 1984), it would take about $3.6-5.7 \mathrm{~h}$ for one seal to catch its quota of penguins. Fur seal pups provide more energy than penguins, per individual captured: 1-2-month-old fur seal pups, weighing 9-12 kg, provide 86-129.6 MJ of energy (gross energy for a $9 \mathrm{~kg}$ pup $=9.56 \mathrm{MJ} / \mathrm{kg}$ and for a $12 \mathrm{~kg}$ pup $=10.8 \mathrm{MJ} / \mathrm{kg}$ : Arnould, Boyd \& Socha, 1996; Arnould, Boyd \& Speakman, 1996), compared with $42.7 \mathrm{MJ}$ for a $4.5 \mathrm{~kg}$ adult chinstrap penguin (gross energy for a $4.5 \mathrm{~kg}$ penguin $=9.5 \mathrm{MJ} / \mathrm{kg}$ : Myrcha \& Kaminski, 1982). With the hunting rates observed at Seal Island (1.4-4 pups/h), one leopard seal could easily provide for itself. Given the typical widely spaced distribution of individual leopard seals (Gilbert \& Erickson, 1977) and the high probability of a single hunter capturing a penguin or fur seal, it seems unlikely that co-operative hunting would become a common hunting strategy. 
Many interesting questions remain unanswered about the nature of interactions between leopard seals. Genetic analysis of tissue from interacting leopard seals would allow a more complex interpretation of the relationship between the seals. More observations of leopard seal behaviour, especially underwater, will help to assess the nature of interactions. More detailed studies of leopard seal pups after they are weaned may shed some light on the movements of young seals and on whether they associate with unrelated adults after they leave the pack ice.

\section{Acknowledgements}

This research was supported by NOAA's National Marine Fisheries Service as part of its Antarctic Marine Living Resources Program. We thank those who helped extensively with leopard seal observations at Seal Island: J. Bengtson, D. Croll, M. Goebel, H. Huber, J. Jansen, W. Meyer, S. Osmek and B. Walker. We thank G. Court, J. Grey, G. Kooyman and T. Mader for sharing their unpublished observations of leopard seals. The manuscript was significantly improved by comments from J. Bengtson, M. Dalheim, R. DeLong, J. Jansen, G. Kooyman, and two anonymous reviewers. W. Cobb and R. Holt documented the observation of a leopard seal capturing a penguin on the beach. We thank the captain, officers and crew of the NOAA ship Surveyor for logistical support.

\section{REFERENCES}

Arnould, J. P. Y., Boyd, I. L. \& Socha, D. G. (1996). Milk consumption and growth efficiency in Antarctic fur seal (Arctocephalus gazella) pups. Can. J. Zool. 74: 254-266.

Arnould, J. P. Y., Boyd, I. L. \& Speakman, J. R. (1996). Measuring the body composition of Antarctic fur seals (Arctocephalus gazella): validation of hydrogen isotope dilution. Physiol. Zool. 69: 93-116.

Bailey, T. N. (1993). The African leopard. Ecology and behavior of a solitary felid. New York: Columbia University Press.

Bekoff, M. \& Byers, J. A. (1985). The development of behavior from evolutionary and ecological perspectives in mammals and birds. Evol. Biol. 19: 215-286.

Bengtson, J. L. (1982). Reproductive ecology of crabeater and leopard seals along the Antarctic Peninsula. Antarct. J. U. S. 17: 185.

Bester, M. N. (1981). Fur seals (Arctocephalus gazella) and leopard seals (Hydrurga leptonyx) at the Courbet Peninsula, Kerguelen. S. Afr. J. Antarct. Res. 10/11: 35-38.

Bester, M. N. \& Roux, J. P. (1986). Summer presence of leopard seals (Hydrurga leptonyx) at the Courbet Peninsula, Iles Kerguelen. S. Afr. J. Antarct. Res. 16: 29-32.

Borsa, P. (1990). Seasonal occurrence of the leopard seal, Hydrurga leptonyx, in the Kerguelen Islands. Can. J. Zool. 68 : 405-408.

Boveng, P. L., Hiruki, L. M., Schwartz, M. K. \& Bengtson, J. L. (1998). Population growth of Antarctic fur seals: limitation by a top predator, the leopard seal? Ecology 79: 2863-2877.

Boyd, I. L. (1993). Pup production and distribution of breeding Antarctic fur seals (Arctocephalus gazella) at South Georgia. Antarct. Sci. 5: 17-24.
Brockmann, H. J. \& Barnard, C. J. (1979). Kleptoparasitism in birds. Anim. Behav. 27: 487-514.

Brown, K. G. (1957). The leopard seal at Heard Island, 1951-54. ANARE Interim Reports 16: 1-34.

Byrnes, P. A. \& Hood, W. R. (1994). First account of Steller sea lion (Eumetopias jubatus) predation on a California sea lion (Zalophus californianus). Mar. Mamm. Sci. 10: 381-383.

Conroy, J. W. H., White, M. G., Furse, J. R. \& Bruce, G. (1975). Observations on the breeding biology of the chinstrap penguin, Pygoscelis antarctica, at Elephant Island, South Shetland Islands. Br. Antarct. Surv. Bull. 40: 23-32.

Court, G. S. (1996). The seal's own skin game. Nat. Hist. 105(8): $36-41$.

Croxall, J. P. \& Prince, P. A. (1979). Antarctic seabird and seal monitoring studies. Polar Rec. 19: 573-595.

Csordas, S. E. (1963). Leopard seals on Macquarie Island. Vic. Nat. 79: 358-362.

DeMaster, D. P., Thomas, J., Stone, S. \& Andriashek, D. (1980). Biological studies of seals in pack ice habitat. Antarct. J. U.S. 14: $179-180$.

Erb, E. (1993). Some field observations on leopard seals (Hydrurga leptonyx) at Heard Island 1992/93. In Heard Island 1992 ANARE Report: 48-66. Green, K. (Ed.). Kingston: Australian Antarctic Division.

Estève, H. (1959). Note sur le status du léopard de mer, Hydrurga leptonyx, aux Iles Kerguelen. Mammalia 23: 68-71.

Gentry, R. L. (1974). The development of social behavior through play in the Steller sea lion. Am. Zool. 14: 391-403.

Gentry, R. L. \& Johnson, H. (1981). Predation by sea lions on northern fur seal neonates. Mammalia 45: 423-430.

Gilbert, J. R. \& Erickson, A. W. (1977). Distribution and abundance of seals in the pack ice of the Pacific Sector of the Southern Ocean. In Adaptations within Antarctic ecosystems: 703-740. Llano, G. A. (Ed.). Washington, DC: Smithsonian Institution.

Green, K. \& Williams, R. (1986). Observations on food remains in faeces of elephant, leopard and crabeater seals. Polar Biol. 6: $43-45$.

Guinet, C. (1991). Intentional stranding apprenticeship and social play in killer whales (Orcinus orca). Can. J. Zool. 69: 27122716.

Guinet, C. \& Bouvier, J. (1995). Development of intentional stranding hunting techniques in killer whale (Orcinus orca) calves at Crozet Archipelago. Can. J. Zool. 73: 27-33.

Gwynn, A. M. (1953). The status of the leopard seal at Heard Island and Macquarie Island, 1948-1950. ANARE Interim Rep. 3: $1-33$.

Hamilton, J. E. (1939). The leopard seal Hydrurga leptonyx (De Blainville). Discovery Rep. 18: 239-264.

Hanggi, E. B. \& Schusterman, R. J. (1990). Kin recognition in captive California sea lions (Zalophus californianus). J. comp. Psychol. 104: 368-372.

Harcourt, R. (1991). The development of play in the South American fur seal. Ethology 88: 191-202.

Harcourt, R. (1993). Individual variation in predation on fur seals by southern sea lions (Otaria byronia) in Peru. Can. J. Zool. 71: 1908-1911.

Heimlich-Boran, S. L. (1986). Cohesive relationships among Puget Sound killer whales. In Behavioral biology of killer whales: 251-284. Kirkevold, B. C. \& Lockard, J. S. (Eds). New York: Allan R. Liss.

Hofman, R. J., Reichle, R. A., Siniff, D. B. \& Müller-Schwarze, D. (1977). The leopard seal (Hydrurga leptonyx) at Palmer Station, Antarctica. In Adaptations within Antarctic ecosystems: 769-782. Llano, G. A. (Ed.). Washington, DC: Smithsonian Institution.

Hofmeyr, G. J. G. \& Bester, M. N. (1993). Predation on king penguins by Antarctic fur seals. S. Afr. J. Antarct. Res. 23: 71-74. 
Hunt, J. F. (1973). Observations on the seals of Elephant Island, South Shetland Islands, 1970-71. Br. Antarct. Surv. Bull. 36: 99-104.

Jansen, J. K., Boveng, P. L. \& Bengtson, J. L. (1998). Foraging modes of chinstrap penguins: contrasts between day and night. Mar. Ecol. Prog. Ser. 165: 161-172.

Kooyman, G. L. (1965). Leopard seals of Cape Crozier. Animals 6: $58-63$.

Kooyman, G. L., Croll, D., Stone, S. \& Smith, S. (1990). Emperor penguin colony at Cape Washington, Antarctica. Polar Rec. 26: 103-108.

Latour, P. B. (1981). Interactions between free-ranging, adult male polar bears (Ursus maritimus Phipps): a case of adult social play. Can. J. Zool. 59: 1775-1783.

Laws, R. M. (1957). On the growth rates of the leopard seal, Hydrurga leptonyx (DeBlainville, 1820). Saugetierkd. Mitt. 5 49-55.

Laws, R. M. (1977). Seals and whales of the southern ocean. Phil. Trans. R. Soc. Lond. B. 279: 81-96.

Laws, R. M. (1984). Seals. In Antarctic ecosystems 2: 621-715. Laws, R. M. (Ed.). London: Academic Press.

Le Roux, P. G. \& Skinner, J. D. (1989). A note on the ecology of the leopard (Panthera pardus Linnaeus) in the Londolozi Game Reserve, South Africa. Afr. J. Ecol. 27: 167-171.

Lopez, H. C. \& Lopez, D. (1985). Killer whales of Patagonia and their behavior of intentional stranding while hunting nearshore. J. Mammal. 66: 181-183.

Lowry, L. F., Testa, J. W. \& Calvert, W. (1988). Notes on winter feeding of crabeater and leopard seals near the Antarctic Peninsula. Polar Biol. 8: 475-478.

Marlow, B. J. (1967). Mating behaviour in the leopard seal, Hydrurga leptonyx (Mammalia: Phocidae), in captivity. Aust. J. Zool. 15: 1-5.

Maynard-Smith, J. (1974). The theory of games and the evolution of animal conflicts. J. theor. Biol. 47: 209-221.

Müller-Schwarze, D. (1971). Behavior of Antarctic penguins and seals. In Research in the Antarctic: 250-276. Quam, L. O. (Ed.). Washington, DC: Am. Assoc. Adv. Sci. Pub. No. 93.

Müller-Schwarze, D. (1984). The behavior of penguins. Albany: State University of New York Press.

Müller-Schwarze, D. \& Müller-Schwarze, C. (1975). Relations between leopard seals and Adélie penguins. Rapp. P.-v. Reun. Cons. Int. Explor. Mer 169: 394-404.

Myrcha, A. \& Kaminski, P. (1982). Changes in body calorific values during nestling development of penguins of the genus Pygoscelis. Pol. Polar Res. 3: 81-88.

Øritsland, T. (1977). Food consumption of seals in the Antarctic pack ice. In Adaptations within Antarctic ecosystems: 749-768. Llano, G. A. (Ed.). Washington, DC: Smithsonian Institution.

Packer, C. \& Ruttan, L. (1988). The evolution of cooperative hunting. Am. Nat. 132: 159-198.

Paulian, P. (1953). Pinnipèdes, cétacés et oiseaux des Iles Kerguelen et Amsterdam. Mém. Inst. Scient. Madagascar, Sér. A 8: 111-234.

Penney, R. L. \& Lowry, G. (1967). Leopard seal predation on Adélie penguins. Ecology 48: 878-882.
Pitcher, K. W. \& Fay, F. H. (1982). Feeding by Steller sea lions on harbor seals. Murrelet Summer: 70-71.

Rasa, O. A. E. (1971). Social interaction and object manipulation in weaned pups of the northern elephant seal Mirounga angustirostris. Z. Tierpsychol. 29: 82-102.

Riedman, M. (1990). The pinnipeds: seals, sea lions and walruses. Berkeley: University of California Press.

Rogers, T. \& Bryden, M. M. (1995). Predation of Adélie penguins (Pygoscelis adeliae) by leopard seals (Hydrurga leptonyx) in Prydz Bay, Antarctica. Can. J. Zool. 73: 1001-1004.

Rogers, T. L., Cato, D. H. \& Bryden, M. M. (1996). Behavioral significance of underwater vocalizations of captive leopard seals, Hydrurga leptonyx. Mar. Mamm. Sci. 12: 414- 427.

Rounsevell, D. \& Eberhard, I. (1980). Leopard seals, Hydrurga leptonyx (Pinnipedia), at Macquarie Island from 1949 to 1979. Aust. Wildl. Res. 7: 403-415.

Schaller, G. B. \& Cranshaw, P. G., Jr. (1980). Movement patterns of jaguar. Biotropica 12: 161-168.

Shaughnessy, P. D. (1990). Bird and mammal life recorded during the Antarctic drift of SY Aurora, 1915-16. Polar Rec. 26: 277288.

Shaughnessy, P. D. \& Goldsworthy, S. D. (1990). Population size and breeding season of the Antarctic fur seal Arctocephalus gazella at Heard Island - 1987/88. Mar. Mamm. Sci. 6: 292-304.

Shaughnessy, P. D., Erb, E. \& Green, K. (1998). Continued increase in the population of antarctic fur seals, Arctocephalus gazella, at Heard Island, Southern Ocean. Mar. Mamm. Sci. 14: $384-389$.

Siniff, D. B. \& Bengtson, J. L. (1977). Observations and hypotheses concerning the interactions among crabeater seals, leopard seals, and killer whales. J. Mammal. 58: 414 416.

Siniff, D. B., Stirling, I., Bengtson, J. L. \& Reichle, R. A. (1979). Social and reproductive behavior of crabeater seals (Lobodon carcinophagus) during the austral spring. Can. J. Zool. 57: 2243-2255

Siniff, D. B. \& Stone, S. (1985). The role of the leopard seal in the tropho-dynamics of the Antarctic marine ecosystem. In Antarctic nutrient cycles and food webs: 555-560. Siegfried, W. R., Condy, P. R. \& Laws, R. M. (Eds). Berlin: SpringerVerlag.

Sokal, R. R. \& Rohlf, F. J. (1981). Biometry. 2nd edn. New York: W. H. Freeman.

Tavolga, M. C. \& Essapian, F. S. (1957). The behavior of the bottle-nosed dolphin (Tursiops truncatus): mating, pregnancy, parturition and mother-infant behavior. Zoologica 42: $11-31$.

Walker, A. R., Boyd, I. L., McCafferty, D. J., Huin, N., Taylor, R. I. \& Reid, K. (1998). Seasonal occurrence and diet of leopard seals (Hydrurga leptonyx) at Bird Island, South Georgia. Antarct. Sci. 10: 75-81.

Wild, F. (1923). Shackleton's last voyage. The story of the 'Quest'. Appendix II, Natural history. London: Cassell \& Co.

Williams, T. D. \& Croxall, J. P. (1991). Annual variation in breeding biology of macaroni penguins, Eudyptes chrysolophus, at Bird Island, South Georgia. J. Zool. (Lond.) 223: 189-202. 